\title{
VEGF I 2 I Rekombinan Dapat Memperbaiki Endoteliosis Gromerular pada Mencit Bunting Model Preeeklampsia
}

\author{
VEGF I2I Recombinant Repairs Glomerular Endotheliosis in Preeclampsia Mice Model
}

Sri Sulistyowati, Donny Irawan, Eric Edwin, Soetrisno

Departemen Obstetri dan Ginekologi, Fakultas Kedokteran,

Universitas Sebelas Maret, Surakarta

\begin{abstract}
ABSTRAK
Tujuan: membuktikan pengaruh VEGF 121 rekombinan terhadap perbaikan endoteliosis glomerular pada mencit model preeklampsia.

Bahan dan Metode: metode eksperimental analitik dengan RCT, yang dilakukan pada bulan Januari - Mei 2015 di Kandang Hewan Percobaan dan Laboratorium Biomedik Fakultas Kedokteran Hewan Universitas Airlangga. Sampel dari replikasi Steel dan Torrie adalah 30 mencit bunting yang terbagi dalam 3 kelompok yaitu 10 mencit bunting normal, 10 mencit bunting model preeklampsia dan 10 mencit bunting model preeklampsia dengan terapi VEGF 121 rekombinan. Semua sampel dilakukan pemeriksaan pada endotel ginjalnya dengan metode imunohistokimia. Parameter endoteliosis glomerular menggunakan kriteria Stillman (2007) dan Wide-Swensson (2007). Analisa data menggunakan uji Kruskal Wallis dan Mann Whitney.

Hasil: Rerata endoteliosis gromeruler pada mencit bunting normal 1,60 dan mencit bunting model preeklampsia 1,90 dengan nilai $\mathrm{p}=0,28 \quad(\mathrm{p}>0,05)$. Rerata endoteliosis gromeruler pada mencit bunting model preeklampsia 1,90 dan mencit bunting model preeklampsia dengan terapi VEGF rekombinan 121 adalah 1,30 dengan nilai $\mathrm{p}=0,02 \quad(\mathrm{p}<0,05)$. Rerata endoteliosis gromeruler pada mencit bunting normal 1,60 dan mencit bunting model preeklampsia dengan terapi VEGF rekombinan 121 adalah 1,30 dengan nilai $\mathrm{p}=0,28(\mathrm{p}>0,05)$.

Simpulan: VEGF 121 rekombinan dapat memperbaiki endoteliosis gromerular pada mencit bunting model preeeklampsia.
\end{abstract}

Kata Kunci: VEGF 121 rekombinan, endoteliosis glomerular, preeklampsia

\begin{abstract}
Objectives: to prove the effect of VEGF 121 recombinant to repair glomerular endoteliosis in mice preeclampsia model. Materials and Methods: This study is an experimental analytic with RCT design. This study was conducted from January to May 2015 held at the Animal Experiments Cage and Biomedical Laboratory Faculty of Veterinary Medicine, Airlangga University. Sample from replication formula Steel and Torrie are 30 pregnant mice divided into 3 groups. There are : 10 normal pregnant mice, 10 preeclampsia model mice and 10 preeclampsia model mice with VEGF 121 recombinant therapy. All of the sample has been examine on the endothel of the renal with immunohistochemistry method. This research tool uses Isaac (2007) and Swensson (2007) criteria to assesing glomerular endotheliosis. The data were analyzed using Kruskal Wallis and Mann Whitney.

Results: The mean of glomerular endotheliosis on the normal pregnant mice $=1,60$ and on the preeclampsia model $=1,90$ with $p=0,28(p>0,05)$. The mean of glomerular endotheliosis on the preeclampsia model $=1,90$ and on the preeclampsia model with VEGF 121 recombinant therapy $=1,30$ with $p=0,02(p<0,05)$. The mean of glomerular endotheliosis normal pregnant mice $=1,60$ and on the preeclampsia model with VEGF 121 recombinant therapy $=1,30$ with $p=0,28(p>0,05)$.

Conclusion: VEGF 121 recombinant can repair glomerular endotheliosis in preeclampsia mice model.
\end{abstract}

Keywords: VEGF 121 recombinant, glomerular endotheliosis, preeclampsia

Correspondence: Sri Sulistyowati, Divisi Fetomaternal, Departemen Obstetri dan Ginekologi, Fakultas Kedokteran, Universitas Sebelas Maret, RSUD Dr. Moewardi, Jalan Kol. Sutarto 132, Surakarta, Indonesia. Telp. : 08122968215. Email: elis_spog@yahoo.co.id

\section{PENDAHULUAN}

Preeklampsia merupakan komplikasi kehamilan yang ditandai dengan peningkatan tekanan darah disertai proteinuria pada wanita hamil dengan umur kehamilan $\geq 20$ minggu. ${ }^{1}$ Prevalensi kejadian preeklampsia sekitar $5 \%-15 \%$ dari keseluruhan kehamilan di dunia, dimana jumlahnya cenderung meningkat dan merupakan komplikasi medis tersering dalam kehamilan. Sekitar $70 \%$ wanita yang didiagnosis hipertensi dalam kehamilan merupakan kasus preeklampsia. ${ }^{2}$ Di Indonesia $30-$ $40 \%$ kasus preeklampsia menjadi penyebab kematian ibu hamil dan 30 - 50\% menjadi penyebab kematian perinatal. Di RSUD Dr. Moewardi Surakarta kematian ibu hamil yang disebabkan oleh preeklampsia yaitu 67,6\% (37 kasus preeklampsia dari 1956 persalinan) pada tahun $2008 .^{3}$

Preeklampsia diyakini terjadi dalam dua tahap. Tahap pertama pada stadium preklinik, yaitu pada proses endotelialisasi dimana terjadi gangguan sitotrofoblas serta invasi arteri spiralis pada miometrium yang tidak adekuat yang menyebabkan terjadinya iskhemia dan hipoksia pada plasenta. Tahap kedua terjadi pada 
kehamilan lanjut, yaitu adanya iskhemi dan hipoksia plasenta menyebabkan pelepasan protein antiangiogenik Solube fms-like tyrosine kinase 1 (sFlt-1), prostaglandin, dan sitokin ke dalam sirkulasi maternal yang akan menekan produksi faktor proangiogenik placenta growth factor (PIGF) dan vascular endothelial growth factor (VEGF). Ketidakseimbangan antara faktor proangiogenik VEGF dan faktor antiangiogenik sFlt-1 diduga terlibat dalam patogenesis preeklampsia. ${ }^{4}$

Pada preeklampsia terjadi gangguan filtrasi di ginjal meliputi; penurunan Glomerular Filtration Rate (GFR), proteinuria, hiperurisemia, dan kerusakan endotel glomerulus yang dapat berujung pada gagal ginjal. ${ }^{5}$ Perubahan tersebut disebabkan oleh disfungsi endotel ginjal yang diduga dipicu oleh ketidakseimbangan antara faktor proangiogenik VEGF dan antiangiogenik sFlt-1 yang masuk ke sirkulasi maternal.6 VEGF dihasilkan oleh sel podocytes yang merupakan faktor penting untuk menjaga fungsi endotel. Sebaliknya sFlt-1 merupakan protein yang dihasilkan oleh plasenta yang mampu berikatan pada VEGFR1 dan dapat menghambat signal VEGF.

Kerusakan endotel ginjal pada preeklampsia disebut sebagai endoteliosis glomerular, yaitu terjadinya pelebaran dan pengerasan dari dinding glomeruli dengan sedikit aliran darah (bloodless) yang menyebabkan penyempitan bahkan sumbatan dari lumen kapiler yang akan berujung pada pembengkakan dari sel podocytes, sel mesangial dan sumbatan/ oklusi di lumen kapiler dari glomerulus yang dapat digambarkan seperti pembengkakan dari sel endokapiler. Sekitar $67 \%$ wanita hamil dengan preeklampsia memiliki endoteliosis glomerular setelah dilakukan biopsi ginjal, setelah melahirkan, endotel glomerulus dapat kembali normal. ${ }^{7}$

Penelitian ini menggunakan hewan coba mencit (Mus musculus) karena berdasarkan pertimbangan bahwa mencit paling sering dipakai dalam penelitian biomedik, karena secara genetik mempunyai kemiripan dengan manusia serta mempunyai kemampuan beradaptasi hidup dalam lingkungan laboratorium. ${ }^{3}$ VEGF 121 rekombinan merupakan VEGF eksogen yang mengandung protein proangiogenik, berperan terhadap proses vaskulogenensis dan angiogenesis, mempunyai reseptor di dinding endhotel yaitu VEGR-1 dan terikat kuat dengan sFlt-1. Pengobatan dengan pemberian VEGF 121 rekombinan memiliki kemampuan menghambat sirkulasi sFlt-1 dalam darah, menurunkan tekanan darah maternal, perbaikan fungsi endotel dan mengurangi hipoksia plasenta. ${ }^{8}$ VEGF 121 rekombinan adalah salah satu bentuk VEGF yang bisa memicu proses angiogenesis sehingga dapat memperbaiki ketidakseimbangan proangiogenik dan antiangiogenik pada preeklampsia. . Penelitian ini bertujuan untuk mengetahui pengaruh
VEGF 121 rekombinan terhadap perbaikan endoteliosis glomerular pada mencit (Mus musculus) model preeklampsia.

\section{BAHAN DAN METODE}

Penelitian ini merupakan penelitian eksperimental analitik (ekspanatorik) dengan rancang bangun Randomized Control Trial (RCT) yang dilakukan pada bulan Januari sampai dengan Mei 2015 di Kandang Hewan Percobaan Fakultas Kedokteran Hewan Universitas Airlangga untuk proses membuntingkan mencit dan membuat mencit bunting model preeklampsia dan memberikan terapi VEGF 121 rekombinan terhadap mencit model preeklampsia serta memelihara mencit bunting sampai dengan pengambilan sampel yaitu hari ke 16 kebuntingan dan Laboratorium Biomedik Fakultas Kedokteran Hewan Universitas Airlangga untuk pembuatan preparat blok parafin dan pemeriksaan imunohistokimia sampel penelitian.

Penelitian pada hewan coba menggunakan organ ginjal mencit yang memenuhi kriteria inklusi yaitu berasal dari mencit betina Mus musculus galur Swiss diperoleh dari pusat Veterinaria Farma Surabaya. Dalam penelitian ini diperoleh mencit betina umur 3 bulan, sehat, dengan berat badan $20-25$ gram. Pengambilan sampel preparat dilakukan pada ginjal mencit yang sebelumnya telah dibedah dan dilakukan blok parafin kemudian diberikan pewarnaan Hematoxylin Eosin (HE). Besar sampel berdasarkan rumus replikasi dari Steel dan Torrie adalah 30 sampel yang terbagi menjadi 3 kelompok yaitu kelompok pertama (K1) mencit bunting normal, kelompok kedua (K2) mencit model preeklampsia dan kelompok ketiga (K3) mencit model preeklampsia yang mendapat terapi VEGF 121 rekombinan. ${ }^{10}$ Pada hari ke16 masa bunting mencit, dari ketiga kelompok dilakukan pembedahan dan diambil ginjalnya. Alasan pengambilan pada hari ke-16 adalah diasumsikan seperti kehamilan trimester kedua pada kehamilan manusia, dimana pada trimester kedua manifestasi preeklampsia sudah muncul pada manusia.

Cara membuntingkan mencit yaitu melakukan sinkronisasi birahi yaitu mencit betina dewasa usia 3 bulan dengan berat badan $20-25$ gram disuntik 5 IU hormon Pregnant More Serum Gonadotropin (PMSG), 48 jam kemudian disuntik 5 IU Human Chorionic Gonadotropin (hCG). Mencit betina tersebut dikawinkan secara monomating, yaitu satu persatu mencit betina yang sudah disinkronisasi birahi dimasukkan ke dalam kandang yang berisi satu mencit jantan umur 7 bulan berat \pm 60 gram, 17 jam setelah dikawinkan mencit dapat didiagnosis bunting bila terdapat copulatory plug 
(sumbat yang menutupi vagina mencit dari serviks sampai vulva).

Pada hari ke-1 kebuntingan, seluruh sampel dibagi menjadi tiga kelompok, yaitu : kelompok mencit bunting normal (K1) 10 ekor dipelihara tanpa intervensi, mencit bunting model preeklampsia (pada hari ke-1 sampai dengan hari ke-4 kehamilan diberikan anti Qa-2 sebanyak $10 \mathrm{ng}$ iv agar menjadi model preeklampsia (Sulistyowati, 2010) 20 ekor yang terbagi dalam K2 dan K3. Pada hari ke 12 - 15 kebuntingan mencit pada kelompok model preeklampsia diberikan VEGF 121 rekombinan $125 \mathrm{mg} / \mathrm{kgBB}$ satu kali (10 ekor K3) Pada hari ke-16 kehamilan mencit Mus musculus dimana pada manusia dianalogkan trimester dua pada kehamilan, dilakukan terminasi pada ketiga kelompok. Tikus kemudian dieutanasi menggunakan ketamin dan dilanjutkan dengan nekropsi. Setelah terbuka rongga abdomen, organ ginjal diambil dan dimasukkan ke dalam pot yang sudah berisi Netral Buffer Formalin $10 \%$.

Pembuatan preparat histologis dilakukan dengan cara organ ginjal difiksasi dengan menggunakan larutan Netral Buffer Formalin 10\% kemudian dipotong dan dimasukkan ke dalam tempat specimen yang terbuat dari plastik. Selanjutnya dilakukan proses dehidrasi dengan alkohol konsentrasi bertingkat yaitu alkohol $70 \%, 80 \%, 90 \%$ alkohol absolute I, absolute II masingmasing 2 jam. Lalu dilakukan penjernihan dengan xylol kemudian dicetak menggunakan paraffin sehingga sediaan tercetak di dalam blok parafin dan disimpan dalam lemari es. Blok parafin tersebut kemudian dipotong tipis setebal 5-6 m menggunakan mikrotom. Hasil potongan diapungkan dalam air hangat bersuhu $60^{\circ} \mathrm{C}$ untuk meregangkan agar jaringan tidak melipat. Sediaan kemudian diangkat dan diletakkan dalam gelas objek untuk dilakukan pewarnaan Hematoxylin dan Eosin (HE). Selanjutnya diperiksa dibawah mikroskop cahaya mixon eclip CY1 dengan pembesaran 1000x.

Penghitungan jumlah sel yang mengalami endoteliosis glomerular pada 10 lapang pandang dari setiap preparat blok parafin. Parameter penentuan endoteliosis glo- merular menggunakan kriteria Stillman (2007) dan Swensson (2007), yaitu menemukan tanda perubahan histopatologis meliputi vakuolisasi podosit dan proliferasi sel mesangial. Jumlah sel yang mengalami endoteliosis untuk setiap preparat dicatat kemudian dilakukan penjumlahan untuk mengetahui skoring., ${ }^{7,1}$ Skoring endoteliosis glomerular mengacu pada WideSwensson (2007) ada pada Tabel 1.

Tabel 1. Skoring endoteliosis glomerular

\begin{tabular}{ll}
\hline \multicolumn{1}{c}{ Skor } & \multicolumn{1}{c}{ Gambaran mikroskopis } \\
\hline 0 (Normal) & Tak tampak endoteliosis \\
1 (Ringan) & $<20 \%$ mengalami endoteliosis glomerulus \\
2 (Sedang) & $20-80 \%$ mengalami endoteliosis glomerulus \\
3 (Berat) & $>80 \%$ mengalami endoteliosis glomerulus \\
\hline \multicolumn{2}{l}{ Wide-Swensson (2007) }
\end{tabular}

Analisa data menggunakan software SPSS (Software Package for social Science). Penelitian ini menggunakan skala pengukuran semikuantitatif berupa skoring endoteliosis glomerular. Data dilakukan uji nonparametrik menggunakan Kruskal-Wallis. Apabila didapatkan perbedaan signifikan, untuk melihat perbedaan satu kelompok dibandingkan dengan kelompok lain dilanjutkan dengan uji statistik Mann Whitney. Perhitungan statistik pada penelitian ini menggunakan tingkat kemaknaan 0,05 (confident interval 95\%).

\section{HASIL DAN PEMBAHASAN}

\section{Jumlah endoteliosis glumerular}

Tabel 2 menunjukkan kelompok bunting normal (K1) mempunyai skoring Wideswensson dengan kategori ringan $(<20 \%$ mengalami endoteliosis glomerolus) sebanyak 4 mencit, kelompok model preeklampsia (K2) : 1 mencit dan kelompok model preeklampsia dengan terapi VEGF 121 rekombinan (K3) sebanyak 7 mencit. Sedangkan skoring Wideswensson kategori sedang (20 - $80 \%$ mengalami endoteliosis glomerolus) pada kelompok (K1) sebanyak 6 mencit, kelompok (K2) sebanyak 9 dan kelompok (K3) sebanyak 3 mencit.

Tabel 2. Jumlah endoteliosis glumerular

\begin{tabular}{|c|c|c|c|c|c|c|}
\hline & & & \multicolumn{3}{|c|}{ Kelompok } & \multirow{2}{*}{ Total } \\
\hline & & & $\mathrm{K} 1$ & K2 (model & K3 (model preeklampsia & \\
\hline \multirow{4}{*}{$\begin{array}{c}\text { Skoring } \\
\text { Wideswensson }\end{array}$} & \multirow{2}{*}{ Ringan } & Jumlah & 4 & 1 & 7 & 12 \\
\hline & & Prosentase & $33.3 \%$ & $8.3 \%$ & $58.3 \%$ & $100.0 \%$ \\
\hline & \multirow{2}{*}{ Sedang } & Jumlah & 6 & 9 & 3 & 18 \\
\hline & & Prosentase & $33.3 \%$ & $50.0 \%$ & $16.7 \%$ & $100.0 \%$ \\
\hline \multicolumn{2}{|l|}{ Total } & Jumlah & 10 & 10 & 10 & 30 \\
\hline
\end{tabular}


Tabel 3. Rerata endoteliosis glomerular pada ketiga kelompok mencit penelitian

\begin{tabular}{clcc}
\hline No & \multicolumn{1}{c}{ Pasangan Kelompok } & Mean & P \\
\hline 1 & $\begin{array}{l}\text { Kelompok (K1) - Kelompok } \\
(\text { K2 })\end{array}$ & $1,60-1,90$ & 0,280 \\
2 & $\begin{array}{l}\text { Kelompok (K1) - Kelompok } \\
(\mathrm{K} 3)\end{array}$ & $1,60-1,30$ & 0,280 \\
3 & $\begin{array}{l}\text { Kelompok (K2) - Kelompok } \\
(\mathrm{K} 3)\end{array}$ & $1,90-1,30$ & $0,023^{*}$ \\
\hline (*) Nilai Signifikan p<0,05 $^{2}$ & &
\end{tabular}

\section{Kelompok Bunting Normal (KI) dengan Kelompok Model Preeklampsia (K2)}

Rerata skoring endoteliosis glomerular pada $\mathrm{K} 1=1,60$ dan $\mathrm{K} 2=1,90$ dengan $\mathrm{p}=0,280(>0,05)$ sehingga secara statistik tidak berbeda secara signifikan. Kelompok Bunting Normal (K1) dengan Kelompok Model Preeklampsia dengan Terapi VEGF 121 Rekombinan (K3). Rerata skoring endoteliosis glomerular pada $\mathrm{K} 1=1,60$ dan $\mathrm{K} 3=1,30$ dengan $\mathrm{p}=0,280(>0,05)$ sehingga secara statistik tidak berbeda secara signifikan. Kelompok Model Preeklampsia (K2) dengan Kelompok Model Preeklampsia dengan Terapi VEGF 121 Rekombinan (K3). Rerata skoring endoteliosis glomerular pada $\mathrm{K} 2=1,90$ dan $\mathrm{K} 3=1,30$ dengan $\mathrm{p}=0,023 \quad(<0,05)$ sehingga secara statistik berbeda secara signifikan.

Pada Gambar 1 terlihat gambaran histologis glomerulus pada mencit bunting normal (K1): terlihat tidak adanya proliferasi mesangial/matriks mesangial (panah 1). Tidak terlihat vakuolisasi sel podosit (panah 2) dan eritrosit masih terlihat pada lumen kapiler pembuluh darah (panah 3), dengan dinding kapiler yang tipis (normal).
Pada preparat ini tidak terlihat adanya endoteliosis glomerular. Pada mencit model preeklamsia (K2): terlihat proliferasi mesangial/matriks mesangial yang massif (panah 1), sehingga menyebabkan penyempitan pembuluh darah (panah 3). Adanya vakuolisasi sel podosit (panah 2) dimana hal ini ditandai adanya kavitas yang abnormal atau vesikel yang terisi penuh oleh cairan di sitoplasma yang merubah sel epitel lapisan viseral dari kapsula Bowman di korpuskulum ginjal, hal ini sering megindikasikan adanya cedera pada podosit. Pada preparat ini dengan adanya proliferasi mesangial atau matriks mesangial yang masif dan vakuolisasi sel podosit merupakan endoteliosis glomerular.

Pada mencit model preeklamsia dengan pemberian VEGF 121 rekombinan (K3): terlihat proliferasi mesangial/matriks mesangial yang tidak massif-mendekati normal (panah 1).Tampak eritrosit terlihat pada lumen kapiler pembuluh darah (panah 3), dengan dinding kapiler yang masih terlihat tebal pada beberapa lumen kapiler pembuluh darah. Masih terlihat adanya vakuolisasi sel podosit (panah 2). Pada preparat ini dengan adanya proliferasi mesangial atau matriks mesangial yang tidak massif-mendekati normal dan vakuolisasi sel podosit endoteliosis glomerular tergambar adanya perbaikan endoteliosis glomerular.

Pada hasil perhitungan keseluruhan preparat didapatkan persentase vakuolisasi podosit pada preparat K1 sebesar 11,9\%,K2 sebesar 18\%, dan K3 sebesar 9,7\%. Sedangkan hasil perhitungan proliferasi sel mesengial keseluruhan preparat didapatkan persentase pada preparat K1 sebesar 24,8\%,K2 sebesar 49,3\%, dan K3 sebesar $23,9 \%$.
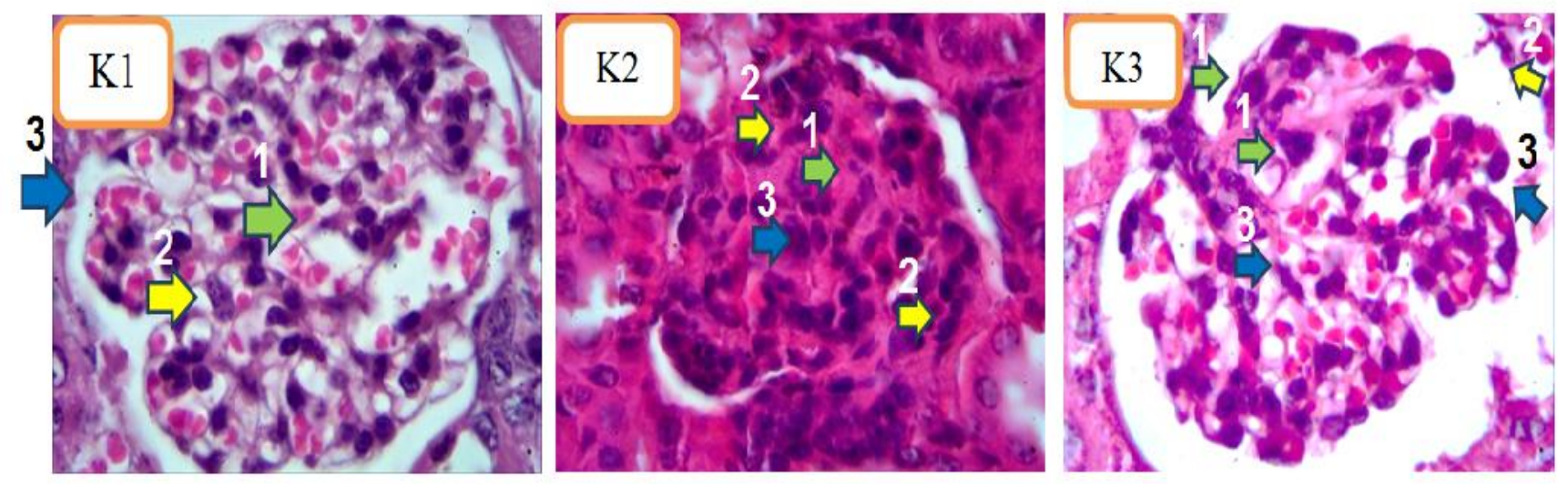

Gambar 1. Perbandingan histopatologis ginjal antara Mus musculus bunting normal (K1), model preeklampsia (K2) dan model preeklampsia dengan terapi VEGF 121 rekombinan (K3) 
Ketidakseimbangan sFlt-1 dan VEGF akan memicu terjadinya endoteliosis glomerular pada preeklampsia.5 Pada penelitian ini didapatkan endoteliosis glomerular pada kelompok mencit model preeklampsia (K2) berbeda bila dibandingkan kelompok mencit bunting normal (K1), tetapi dari hasil uji statistik skoring endoteliosis glomerular didapatkan hasil p sebesar 0,280 ( $p>0,05)$ sehingga didapatkan perbedaan yang tidak signifikan. Hasil tersebut tidak sesuai dengan teori, bahwa endoteliosis glomerular pada kelompok mencit model preeklampsia lebih banyak dibanding kelompok bunting normal. Perbedaan hasil pada kelompok mencit model preeklampsia (K2) dengan kelompok mencit bunting normal (K1) adalah pada skoring Wideswensson yaitu kategori ringan sebanyak 4 mencit dan pada K2 dan 1 mencit pada K1. Skoring Wideswensson kategori sedang pada K1 sebanyak 6 mencit dan pada K2 9 mencit yang menunjukkan bahwa tetap terdapat perbedaan kejadian endoteliosis glomerulus, hanya secara statistik tidak menunjukkan perbedaan yang signifikan. Pada preeklampsia terjadi penurunan ekspresi VEGF dan disfungsi endotel yang meyebabkan endoteliosis glomerular yanitu terjadinya pelebaran dan pengerasan dinding glomeruli atau oklusi di lumen kapiler glomerulus, proliferasi mesangial dan vakuolisasi sel podosit. $^{7}$

VEGF menginduksi terjadinya angiogenesis dan proliferasi sel endotel serta berperan penting dalam proses vaskulogenesis.14 VEGF merupakan promoter yang kuat terhadap angiogenesis yaitu memperbaiki fungsi sel endotel dengan menginduksi Nitrit Oksida dan vasodilatasi, juga menurunkan tekanan vaskuler dan tekanan darah. ${ }^{13}$ Pada penelitian ini kejadian endoteliosis glomerular pada kelompok mencit model preeklampsia (K2) berbeda jika dibandingkan pada kelompok mencit model preeklampsia yang diberi terapi VEGF 121 Rekombinan (K3) dengan nilai $p=0,023$ $(p<0,05)$. Hasil penelitian ini sesuai dengan teori bahwa pemberian VEGF eksogen akan memperbanyak ikatan antara sFlt-1 dengan kedua antagonisnya yaitu VEGF dan PIGF. VEGF 121 rekombinan adalah VEGF eksternal yang merupakan protein bersifat proangiogenik yang berperan pada proses vaskulogenesis dan angiogenesis, VEGF 121 rekombinan mempunyai reseptor di dinding endhotel yaitu VEGR-1 dan bisa terikat juga dengan ikatan yang lebih kuat pada sFlt-1. VEGF 121 rekombinan berikatan dengan VEGFR-1 sehingga memicu proses angiogenesis. Pemberian terapi VEGF 121 rekombinan juga bisa menetralisasi efek dari peningkatan sFlt-1 pada preeklampsia sehingga pengikatan sFlt-1 ke faktor proangiogenik bisa menurun dan fungsi angiogenesis kembali normal.9 Oleh karena itu terapi VEGF 121 rekombinan sangat berpengaruh pada perbaikan fungsi ginjal terutama pada fungsi sel endotel glomerulus.15 Penelitian ini memperlihatkan gambaran histopatologis ginjal berupa endotiliasis glomerular yang mengalami perbaikan yaitu adanya involusi sel Podosit dan involusi sel mesangial pada Mus musculus model preeklampsia yang mendapat perlakuan VEGF 121 Rekombinan.

Pada kehamilan normal di glomerulus lumen kapiler terbuka tidak ada obliterasi, sel mesangial tidak mengalami proliferasi dan sel podosit normal. Pada penelitian ini endoteliosis glomerular pada kelompok mencit bunting normal (K1) tidak berbeda bila dibandingkan pada kelompok mencit model preeklampsia yang diberi terapi VEGF 121 Rekombinan (K3) yaitu $\mathrm{p}=0,280(>0,05)$. Hal ini disebabkan karena pada kelompok mencit bunting normal (K1) tidak terjadi disfungsi endotel. Terapi VEGF 121 Rekombinan yang bertujuan untuk memperbaiki kerusakan endotel pada kondisi preeklampsia akan menunjukkan gambaran histopatologis mendekati normal.

VEGF 121 Rekombinan secara signifikan memperbaiki endoteliosis glomerular dengan memperbaiki patensi kapiler, mengurangi deposit protein, dan mengurangi pembengkakan endotel. VEGF121 Rekombinanbekerja dengan mengikat sFlt-1 yang rusak sehingga memberikan signifikansi reduksi secara histologis. ${ }^{16}$

\section{SIMPULAN}

VEGF 121 rekombinan dapat memperbaiki endoteliosis gromerulus pada mencit Mus musculus model preeklampsia.

\section{DAFTAR PUSTAKA}

1. Wang IK, Muo $\mathrm{CH}$, Chang YC, Liang CC, Chang CT, Lin SY, Yen TH, et al. Association between hypertensive disorders during pregnancy and end stage renal disease: population based study. CMAJ. 2013;185(3):207-13.

2. Han L, Yang Z, Li K, Zou J, Li H, Han J, Zhou L, et al. Antepartum or Immediate Postpartum Renal Biopsies in Preeclampsia of Pregnancy: new Morphologic and Clinical Findings. Int J Clin Exp Pathol. 2014;7(8):5129-43.

3. Sulistyowati S, Abadi A, Hood J, Soetjipto S. The Influence of Low HLA-G Protein Expression on HSP-70 and VCAM-1 Profile in Preeclampsia. Indonesian J Obstet Gynecol. 2010;34(4):185-90.

4. Bdolah Y, Sukhatme VP, Karumanchi SA. Angiogenic Imbalance in the Patophysiology of Preeclampsia: Newer Insight. Semin Nephrol. 2004;24(6):548-56. 
5. Veron D, Villegas G, Aggarwal PK, Bertuccio C, Jimenez J, Velazquez H, Reidy K. Acute Podocyte vascular Endothelial Growt Factor (VEGF-A) Knockdown Disrupts alpa beta3 Integrin Signaling in the Glomerular. PLoS One. 2012;7(7):e40589

6. Craici IM, Wagner SJ, Bailey KR, Fitz-Gibbon PD, Wood-Wentz CM, Turner ST, Hayman SR, et al. Podocyturian Predates Proteinuria and Clinical Features of Preeclampsia: Longitudinal Prospective Studty. Hypertension. 2013;61(6):1289-96.

7. Stillman IE, Karumanchi SA. The Glomerular Injury of Preeclampsia. J Am Soc Nephrol. 2007;(18):2281-4.

8. Shah, Dinesh M. Preeclampsia: new insight, current opinion in Nephrology and Hypertension. 2007;16(3):213-20.

9. Maynard SE, Karumanchi SA. Angiogenic Factors and Preeclampsia. Semin Nephrol. 2011;31(1):3346.

10. Steel RGD, Torrie JH. Principles and Procedures of Statistics: a Biometrical Approach. 2nd Eds. New York: McGraw-Hill Kogakusha; 1980.

11. Wide-Swensson D, Strevens H, Willner J. Antepartum percutaneus renal biopsy. Int J Gynaecol Obstet. 2007;98(2):88-92.
12. Romero R, Nien JK, Espinoza J, Todem D, Fu W, Chung H, Kusanovic JP, et al. A Longitudinal study of angiogenic (placental growth factor) and anti angiogenic (soluble endoglin and soluble vascular endothelial growth factor receptor-1) factors in normal pregnancy and patiensts destined to develop preeclampsia. J Matern Fetal Neonatal Med. 2008;21(1):9-23.

13. Miller-Deile J, Schiffer M. Renal Involvement in Preeclampsia: Similaritues to VEGF Ablation Therapy. J Pregnancy. 2011:176973.

14. Poon LC, Nicolaides KH. Early Prediction of Preeclampsia. Obstet Gynecol Int. 2014:297397.

15. Siddiqui AH, Irani RA, Zhang Y, Dai Y, Blackwell SC, Ramin SM, Rodney E, et al. Recombinant vascular Endothelial Growth Factor 121 Attenuates Autoantibody induced feature of preeclampsia in Pregnant Mice. Am J Hypertens. 2011;24(5):60612.

16. Li Z, Zhang Y, Ying Ma J, Kapoun AM, Shao Q, Kerr I, Lam A, et al. Recombinant Vascular Endothelial Growth Factor 121 Attenuates Hypertension and Improves Kidney Damage in a Rat Model of Preeclampsia. Hypertension. 2007;50(4):686-92. 